\title{
EVALUASI PEMILUKADA DALAM PERSPEKTIF ANGKA GOLPUT DI KECAMATAN GAMBIRAN TAHUN 2015
}

\author{
Mahbub Junaidi \\ Fakultas Ilmu Sosial dan Ilmu Pilitik, Universitas 17 Agustus Banyuwangi \\ email: mahbubfpbi@gmail.com
}

\begin{abstract}
This research try to know and analyze the phenomenon of the white in gambiran on local election and deputy head of the banyuwangi district in 2015. Researchers are most interested in doing this research, with the implementation of the general election there are many people who did not vote (golput) during the election especially the in district gambiran. Given this situation, but this study tries to examine how the golput in kecamatan gambiran and faktor-faktor what sajakah affecting the emergence of golput in district gambiran in pemilhan regional leaders and deputy head of the district banyuwangi in 2015. A theory that used in clarifying these problems were behavioral therapy voters, factors affect voted (golput), and concept of white. But research methodology used was a qualitative methodology descriptive with informants the community in kecamatan gambiran. Background factors such as education socioeconomic, work, and economic conditions gives impact on the community in kecamatan gambiran in no respect voted (golput) during the election. Psychological factors and choice rational also affect them to stay in the election.In this case people still unconvinced against a candidate the head of the region or deputy head candidate regions, because they consider janji-janji on during the campaign not realized when power they have them and policies be given away from a satisfactory. This is what makes people not voted (golput) during the election last
\end{abstract}

Keywords: Evaluation, election, voted. 


\section{PENDAHULUAN}

Setiap pelaksanaan pemilu, baik pemilu legislatif, Pilpres ataupun pemilu kepala daerah (Pilkada) selalu diwarnai dengan munculnya golongan putih atau Golput. Entah kenapa golongan yang satu ini selalu menjadi "sosok' yang mengkhawatirkan dan menakutkan. Disebut mengkhawatirkan karena golongan ini dinilai 'sosok" yang tidak mendukung pesta demokrasi yang sudah berjalan puluhan di negeri ini.

Bagi pemerintah dan penyelenggara pemilu atau pilkada, Golput juga harus dilihat sebagai pendidikan politik bagi masyarakat. Tujuannya untuk membuat orang berpikir kritis. Penguasa tidak berhak memaksakan rakyat untuk menggunakan hak suaranya. Pendirian yang berlainan dengan pendirian penguasa harus dilindungi supaya tradisi berdemokrasi yang sehat senantiasa terpelihara. Pada pemilu mendatang tentu saja pemerintah berharap jumlah Golput bisa terus menipis. Namun harapan itu tentunya mesti dibarengi dengan sikap pemerintah yang bisa menjamin terselenggaranya pemilu yang jujur dan adil.

Partisipasi politik dalam negara demokrasi merupakan indikator implementasi penyelenggaraan kekuasaaan negara tertinggi yang absah oleh rakyat (kedaulatan rakyat), yang dimanifestasikan keterlibatan mereka dalam pesta demokrasi (Pemilu). Semakin tinggi tingkat partisipasi politik mengindikasikan bahwa rakyat mengikuti dan memahami serta melibatkan diri dalam kegiatan kenegaraan. Sebaliknya tingkat partisipasi politik yang rendah pada umumnya mengindikasikan bahwa rakyat kurang menaruh apresiasi atau minat terhadap masalah atau kegiatan kenegaraan. Rendahnya tingkat partisipasi politik rakyat direfleksikan dalam sikap golongan putih (golput) dalam pemilu. Selanjutnya secara eksplisit, Huntington dan Nelson membedakan partisipasi politik kedalam dua karakter, yaitu:

a) Partisipasi yang demokratis dan otonom adalah bentuk partisipasi politik yang sukarela

b) Partisipasi yang dimanipulasi, diarahkan, dan disponsori oleh Pemerintah adalah bentuk partisipasi yang dimobilisasikan.

Di era Orde Baru partisipasi politik yang dimobilisasikan merupakan kontribusi hasil mobilisasi politik yang dilakukan oleh jaringan aparat birokrasi pemerintahan Orde Baru, bersinergi dengan dukungan pengaruh para tokoh-tokoh masyarakat karismatik sebagai panutan yang telah dikooptasi oleh birokrasi pemerintahan sebagai wasit, namun ikut bermain politik sebagai orang Golkar. Kinerja kolaboratif tersebut membuktikan mampu menekan presentase tingkat Golput.

Banyak pandangan tentang pilihan Golput tersebut dan semakin banyaknya masyarakat yang tidak menggunakan hak pilihnya dalam pemilu atau biasa disebut sebagai kelompok golput. Setidak-tidaknya ada beberapa hal penting tentang kenapa harus menggunaan hak pilihnya dengan baik. Pertama, pilihan untuk tidak memilih (golput) merupakan bentuk pemborosan terhadap anggaran belanja Negara (untuk pemilu) dan APB daerah (untuk pilkada). Padahal, dalam momentum pemilu maupun pilkada, tidak sedikit dana yang dikeluarkan. Kedua, golput juga akan menguntungkan calon yang belum tentu berkualitas atau disukai.

Dalam pemilihan secara langsung seperti saat ini, maka calon yang terpilih akan merasa bahwa ia pilihan "rakyat" dan bebas melakukan apa yang dikehendakinya. Justru hal ini menjadi bumerang bagi golput. Sehingga, hal yang perlu

dilakukan agar dapat mencegah golput yaitu : yang penting adalah melakukan gerakan kultural untuk mengembalikan semangat memilih, menggunakan hak pilih dalam pemilu maupun pilkada untuk melawan budaya golput. Bisa dilakukan kampanye besar-besaran, melibatkan semua kelompok dalam masyarakat. Dan perlunya adanya pendidikan dan sosialisasi politik kepada pemilih, khususnya bagi pemula untuk tidak menjadi golput dan memahami arti pentingnya partisipasi masyarakat dalam Pemilu.

Pada masa reformasi sekarang ini pemaknaan istilah golput telah mengalami pergeseran. Hal itu tidak terlepas adanya perubahan paradigma bahwa memilih bukanlah seperti yang terjadi pada masa orde baru melainkan hak pemilih untuk ikut atau tidak dalam 
pemilu/pilkada. Seiring dengan perubahan paradigma tersebut istilah golput pada saat ini merupakan penyebutan untuk orang-orang yang tidak ikut dalam pemilu atau pilkada. Dengan hanya melihat hasil pemilu atau pilkada maka golput tidak mungkin terdeteksi dengan baik. Sebab hasil pemilu tidak pernah disertai informasi alasan mengapa pemilih ikut memilih, tidak ikut memilih, atau memilih secara salah.

Meskipun tingginya angka golput menjadi gejala umum dalam Pemilu Legislatif di banyak wilayah dan kemungkinan fenomena Golput ini juga akan menjadi gejala umum Pemilu Presiden di masa mendatang, hingga saat ini belum ada penjelasan yang memadai apa yang menyebabkan seorang pemilih memilih tidak menggunakan hak pilihnya. Berbagai penjelasan mengenai golput di Indonesia hingga saat ini masih didasarkan pada asumsi dan belum didasarkan pada riset yang kokoh. Pengamat dan penyelenggara Pemilu memang kerap melontarkan pendapat tentang penyebab rendahnya tingkat partisipasi pemilih. Tetapi berbagai penjelasan itu didasarkan pada pengamatan dan bukan berdasarkan hasil riset.

Hingga saat ini, ada sejumlah penjelasan yang dikemukakan oleh para pengamat atau penyelenggara Pemilu tentang penyebab adanya Golput. Pertama, administratif. Seorang pemilih tidak ikut memilih karena terbentur dengan prosedur administrasi seperti tidak mempunyai kartu pemilih, tidak terdaftar dalam daftar pemilih dan sebagainya. Kedua, teknis. Seseorang memutuskan tidak ikut memilih karena tidak ada waktu untuk memilih seperti harus bekerja di hari pemilihan, sedang ada keperluan, harus ke luar kota di saat hari pemilihan dan sebagainya. Ketiga, rendahnya keterlibatan atau ketertarikan pada politik (political engagement). Seseorang tidak memilih karena tidak merasa tertarik dengan politik, acuh dan tidak memandang Pemilu atau Pilkada sebagai hal yang penting. Keempat, kalkulasi rasional. Pemilih memutuskan tidak menggunakan hak pilihnya karena secara sadar memang memutuskan untuk tidak memilih. Pemilu legislatif dipandang tidak ada gunanya, tidak akan membawa perubahan berarti atau tidak ada calon kepala daerah yang disukai dan sebagainya.

Maka dari penjelasan di atas, masyarakat golongan putih (golput) terbagi atas dua bagian, yaitu masyarakat yang tidak terdaftar sebagai pemilih pada pemilihan dan masyarakat yang terdaftar sebagai pemilih tetapi tidak menggunakan hak pilihnya pada pemilihan. Dalam hal ini peneliti akan meneliti masyarakat golongan putih yang telah terdaftar sebagai pemilih tetapi tidak menggunakan hak pilihnya pada pemilu di tingkat desa. Faktor-faktor apa yang mempengaruhi masyarakat tersebut sehingga tidak menggunakan hak pilihnya pada pemilu di tingkat desa. Mana penjelasan yang lebih cocok untuk fenomena ini, hal ini menjadi latar belakang peneliti untuk fenomena golput sehingga dapat mengetahui apa yang menyebabkan pemilih tidak menggunakan hak pilihnya.

\section{METODE PENELITIAN}

Partisipasi masyarakat dalam pemilu dan pilkada menjadi penentu untuk pengambilan keputusan dalam menentukan wakil rakyat, namun partisipasi politik masyarakat dalam setiap pemilihan terkadang menurun sehingga menciptakan kelompok sendiri yang disebut golput (golongan putih), kelompok ini tidak menggunakan haknya dalam setiap pemilihan kepala daerah yang diselenggarakan lima tahun sekali oleh daerah. Fenomena inilah yang mendorong peneliti ingin melakukan penelitian secara kualitatif. Hal ini dikarenakan dalam penelitian ini menggunakan data kualitatif berupa buku dan artikel baik dari media massa, jurnal maupun website yang memberikan informasi tentang bagaimana partisipasi politik dan perilaku masyarakat yang terkait golput.

Tipe penelitian adalah deskriptif analisis yaitu penelitian yang menggambarkan keadaan

atau peristiwa yang berkaitan dengan partisipasi politik masyarakat yang kemudian menimbulkan golput dalam setiap pilkada. 


\subsection{Unit Analisis}

Dalam tekhnik ini, pengumpulan data dimulai dari beberapa orang yang memenuhi kriteria untuk dijadikan anggota sampel. Mereka kemudian menjadi sumber informasi tentang orang-orang lain yang juga dapat dijadikan anggota sampel dan selanjutnya diminta menunjukkan orang lain yang memenuhi kriteria menjadi anggota sampel. Demikian prosedur ini dilanjutkan sampai jumlah anggota sampel yang diinginkan terpenuhi. Informan golput terdiri dari individu masyarakat biasa maupun tokoh masyarakat. Data yang diperoleh dari wawancara dianalisis secara kualitatif, sehingga diperoleh data yang akurat mengenai faktorfaktor dan penyebab masyarakat menjadi golput secara mendalam.

\subsection{Sumber dan Jenis Data}

Dalam mengumpulkan data dan informasi yang dibutuhkan peneliti mendapatkan sumber dari:

a) Data primer yang didasarkan pada peninjauan langsung pada objek yang diteliti untuk memperoleh data-data yang dibutuhkan. Studi lapangan yang dilakukan dengan datang langsung ke lokasi penelitian dengan cara menyebarkan angket/kuesioner kepada responden yang dijadikan sebagai sampel penelitian. Responden menjawab dengan memilih pilihan jawaban yang telah disediakan dalam daftar pertanyaan.

b) Data sekunder yaitu dengan mencari sumber data dan informasi melalui buku-buku, jurnal, internet dan lain-lain yang berkaitan dengan penelitian ini.

\subsection{Instrumen Penelitian}

a) Kisi-kisi Instrumen

Kisi-kisi instrumen dalam penelitian menunjukkan hubungan antara variabel dengan data, metode, dan instrumen yang disusun. Kisi-kisi instrumen dibuat berdasarkan konsep teori yang mendukung penelitian yang selanjutnya menjadi bahan yang akan dituangkan sebagai angket penelitian.

b) Uji validitas instrumen

Uji validitas dilakukan untuk mengetahui tingkat validitas instrumen. Instrumen dikatakan valid apabila mampu mengukur apa yang diinginkan atau dapat mengungkap data dari variabel yang diteliti secara tepat. Uji validitas dan reabilitas diperlukan dalam penelitian ilmiah yang merupakan dasar untuk mempercayai bahwa instrumen tersebut benar-benar layak digunakan dalam penelitian.

\subsection{Teknik Pengumpulan dan Pengolahan Data}

Untuk mendapatkan data dalam penelitian ini, peneliti menggunakan data primer maupun data sekunder, dipergunakan beberapa teknik penelitian data sebagai berikut:

a) Penelitian kepustakaan, yaitu mempelajari buku-buku, peraturan-peraturan, laporan, dokumen-dokumen serta bahan-bahan lain yang berhubungan dengan penelitian.

b) Penelitian lapangan, yaitu pengumpulan data dengan melakukan wawancara langsung kepada informan yang telah dipilih.

\subsection{Teknik Analisis Data}

Data yang telah dikumpulkan kemudian disusun, dianalisa dan disajikan untuk memperoleh gambaran sistematis tentang kondisi dan situasi yang ada. Data-data tersebut diolah dan dieksporasi secara mendalam yang selanjutnya akan menghasilkan kesimpulan yang menjelaskan masalah yang diteliti. Data yang telah dikumpulkan kemudian disusun, dianalisa dan disajikan untuk memperoleh gambaran sistematis tentang kondisi dan situasi yang ada. Data-data tersebut diolah dan dieksplorasi secara mendalam yang selanjutnya akan menghasilkan kesimpulan yang menjelaskan masalah yang diteliti. 


\section{HASIL DAN PEMBAHASAN}

\subsection{Profil Kecamatan Gambiran}

Kecamatan Gambiran merupakan salah satu kecamatan yang ada di Kabupaten Banyuwangi. Gambiran memiliki 6 desa, diantaranya:

1) Desa Gambiran

2) Desa Jajag

3) Desa Purwodadi

4) Desa Wringinagung

5) Desa Wringinrejo

6) Desa Yosomulyo

Di wilayah Kecamatan Gambiran terdapat berbagai macam sekolah

dari TK/PAUD sampai dengan SMA. Satu-satunya sekolah vodkasi (kejuruan) yaitu SMK Muhammadiyah 9 Gambiran yang lokasinya berdekatan dengan Kantor Kecamatan Gambiran dan RS Al Rohmah Jajag.

\subsection{Keadaan Demografi}

Penduduk Kecamatan Gambiran berjumlah 104.175 jiwa. Dengan jumlah lakilaki 51.462 jiwa dan jumlah perempuan 52.713 jiwa. Agar lebih jelas, komposisi penduduk Kecamatan Gambiran dapat dilihat berdasarkan umur dan jenis kelamin dalam tabel 1.

Tabel 1. Penduduk menurut umur dan jenis kelamin di Kecamatan Gambiran.

\begin{tabular}{|c|c|c|c|}
\hline \multirow{2}{*}{ Kelompok Umur } & \multicolumn{2}{|c|}{ Jenis Kelamin } & \multirow{2}{*}{ Jumlah } \\
\cline { 2 - 3 } & Laki-Laki & Perempuan & \\
\hline $0-4$ & 5.078 & 4.770 & 9.848 \\
\hline $5-9$ & 4.491 & 4.258 & 8.750 \\
\hline $10-14$ & 4.374 & 3.752 & 8.127 \\
\hline $15-19$ & 5.882 & 6.803 & 22.685 \\
\hline $20-24$ & 10.713 & 11.849 & 11.946 \\
\hline $25-29$ & 5.997 & 5.949 & 8.799 \\
\hline $30-34$ & 4.347 & 4.452 & 6.273 \\
\hline $35-39$ & 3.004 & 3.269 & 4.883 \\
\hline $40-44$ & 2.478 & 2.405 & 3.218 \\
\hline $45-49$ & 1.683 & 1.535 & 2.351 \\
\hline $50-54$ & 1.177 & 1.174 & 1.673 \\
\hline $55-59$ & 807 & 866 & 1.428 \\
\hline $60-64$ & 730 & 699 & 1.632 \\
\hline $65+$ & 701 & 932 & 104.175 \\
\hline Jumlah & 51.462 & 52.713 & \\
\hline
\end{tabular}

Sumber: diolah peneliti dari berbagai sumber.

Pada kesempatan kali ini akan dianalisis data yang diperoleh melalui wawancara kepada informan di Kecamatan Gambiran yang terdiri dari masyarakat biasa dan tokoh masyarakat. Data yang akan disajikan dan dianalisis adalah gambaran golongan putih yang ada di Kecamatan Gambiran dan faktor-faktor yang mempengaruhi masyarakat yang telah terdaftar sebagai pemilih tetapi tidak ikut memilih pada pilkada Kabupaten Banyuwangi baru-baru ini.

\subsection{Gambaran Umum Keberadaan Golput di Kecamatan Gambiran}

Pada pilkada daerah Kabupaten Banyuwangi 2015, Kecamatan Gambiran memiliki angka golput mencapai 3 persen dari keseluruhan Daftar Pemilih Tetap (DPT).Golput adalah 
akronim dari golongan putih. Istilah ini ditujukan kepada mereka yang dengan sengaja dan dengan suatu maksud dan tujuan yang jelas menolak memberikan suara dalam pemilu. Dengan demikian, orang-orang yang berhalangan hadir di Tempat Pemungutan Suara (TPS) hanya karena alasan teknis, seperti jauhnya TPS atau terluput dari pendaftaran, otomatis dikeluarkan dari kategori golput. Begitu pula persyaratan yang diperlukan untuk menjadi golput bukan lagi sekedar memiliki rasa enggan atau malas ke TPS tanpa maksud yang jelas. Hal ini dikemukakan pada hasil wawancara salah satu pemilih di Kecamatan Gambiran sebagai berikut

"Pada pilkada kemarin, saya pribadi mengatakan golput pada saat itu dikarenakan saya tidak terlalu percaya terhadap figur calon pasangan yang ada, selain itu suara yang terhitung satu yang saya miliki tidak terlalu berpengaruh juga terhadap hasil pilkada, maka dari itu saya lebih memilih golput dan menjalankan kesibukan yang saya anggap lebih penting."

Berdasarkan hasil wawancara dapat disimpulkan bahwa masyarakat memilih golput dikarenakan mereka tidak terlalu percaya terhadap calon yang maju sebagai kandidat serta mereka beranggapan bahwa suara mereka kelak tidak akan berpengaruh terhadap hasil pemilu/ dapat dikatakan kepercayaan politik yang dimiliki masyarakat masih belum maksimal. Hasil wawancara kedua dengan salah satu masyarakat yang memilih golput pada pilkada Kabupaten Banyuwangi tahun 2015 sebagai berikut:

"Saya tidak memilih karena saya sudah pesimis dengan hasil pemilu, selama ini yang saya lihat, pemilu seakan sia-sia dan tidak ada hasil yang signifikan, apalagi saya juga pesimis dengan kandidatnya, saya kurang yakin mereka jika terpilih dapat membawa perubahan sesuai dengan janji sewaktu kampanye."

Hasil wawancara diatas menunjukkan golput politis yang sangat berhubungan dengan orientasi kandidat dan isu yang melihat bagaimana kepentingan masyarakat yang merasa terwakili oleh kandidat yang dipilihnya. Namun hal tersebut tidak terlihat pada pilkada tahun ini karena sebagian masyarakat yang cenderung golput karena merasa kandidat yang maju bukan keinginan mereka.

\subsection{Faktor-Faktor yang Mempengaruhi Masyarakat yang Sudah Terdaftar Sebagai Pemilih Tetapi Tidak Ikut dalam Pemilihan}

a) Faktor Sosial Ekonomi

Faktor-faktor sosial ekonomi meliputi keadaan sosial dan keadaan ekonomi. Tingginya tingkat kehadiran pemilih dari pemilih yang berpendidikan dan berpenghasilan tinggi. Hasil temuan Verba dan Nie menyimpulkan "the best known about turnout is that citizens of hinger social and economic status participate more in politics." (yang utama tentang kehadiran bahwa warga negara yang status sosial dan ekonomi lebih berpartisipasi politik).

b) Faktor Psikologis

Kedekatan masyarakat dengan salah satu calon kepala daerah dapat menjadi salah satu faktor mengapa masyarakat ikut memilih maupun tidak ikut memilih, pada temuan hasil wawancara di lapangan maypritas masyarakat yangf menjadi informan tidak mempunyai hubungan dengan semua calon kepala daerah. Hal ini berarti bahwa keadaan masyarakat dengan salah satu calon kepala daerah benar-benar mempengaruhi masyarakat untuk ikut atau tidak ikut dalam pemilihan.

c) Faktor Rasional

Faktor rasional ini melihat visi dan misi yang diberikan partai politik harus jelas dan program yang dikemukakan harus menarik simpati para pemilih agar pemilih mau memilih mereka. Namun, apabila para calon kepala daerah tersebut gagal dalam mempromosikan visi dan misi maupun program-programnya kepada pemilih, maka pilihan untuk tidak memilih (golput) rasional bagi pemilih. 


\section{SIMPULAN DAN SARAN}

\section{A. Simpulan}

Hasil penelitian yang dilakukan di Kecamatan Gambiran mengenai perspektif angka golput pada pilkada tahun 2015 memberikan simpulan bahwa keberadaan golongan putih (golput) di Kecamatan Gambiran khususnya pada pemilihan kepala daerah dan wakil kepala daerah Kabupaten Banyuwangi 2015 sangat memprihatinkan. Di lokasi penelitian di Kecamatan Gambiran ditemukan 2 kategori golput berdasarkan alasan dan sebab mereka tidak menggunakan hak suaranya yang pertama yaitu kategori masyarakat golput pragmatis, karena mereka apatis terhadap sistem pemilu yang berjalan pada saat ini dengan asumsi yang terbangun suara yang dimiliki tidak terlalu berpengaruh terhadap hasil pemilu, sedangkan kedua yaitu sebagian masyarakat golput politis. Masyarakat yang tidak punya pilihan dari kandidat yang tersedia atau pesimistis bahwa pemilu/pilkada akan membawa perubahan dan perbaikan mereka mengaku tidak ada satupun kandidat yang sesuai dengan harapannya dan karena itu tidak mau mencoblos.

\section{B. Saran}

Perilaku pemilih masyarakat dalam kegiatan pemilihan yang berupa memberikan sikap tidak ikut serta dalam pemilihan (golput) merupakan fenomena yang sedang sering terjadi dalam pemilu di beberapa daerah di Indonesia saat ini khususnya di Kecamatan Gambiran. Untuk menghindari fenomena ini agar tidak terjadi lagi di masa depan, oleh karena itu dalam proses menyelesaikan penelitian ini ada beberapa saran yang akan menjadi harapan peneliti di masa depan, yaitu :

1) Faktor sosial ekonomi, psikologis, dan faktor rasional memang menjadi faktor yang mempengaruhi masyarakat dalam menentukan sikap pada saat pemilihan umum/pilkada. Di dalam faktor sosial ekonomi, pendidikan sangat berperan karena melalui pendidikan masyarakat dapat menganalisa setiap pilihan yang akan ditetapkan untuk itu masyarakat sebaiknya diberikan pendidikan poitik khususnya tentang wakil-wakil mereka yang akan duduk sebagai pemimpin, sehingga mereka tidak salah pilih dan memahami untuk apa mereka memilih wakil mereka tersebut.

2) Tingkat kepercayaan masyarakat terhadap pelaksanaan pemilu dan partai politik juga sangat minim saat ini, sehingga hal ini perlu diperhatikan oleh semua wakil-wakil rakyat maupun partai-partai politik. Sebaiknya semua calon yang sudah terpilih \& memperoleh kedudukan harus menunjukkan perilaku yang baik dan melakukan pendekatan yang baik kepada masyarakat serta menepati janji-janjinya kepada masyarakat pada saat berkampanye. Jangan memberikan janji-janji hanya pada saat masa kampanye saja. Akan tetapi semua wakilwakil rakyat beserta partai politik yang mengusungnyaharus benar-benar menjalankan semua program kerjanya dengan baik yang mereka berikan pada saat kampanye mereka berlangsung. Dengan demikian, kepercayaan masyarakat terhadap pelaksanaan pemilu akan meningkat dan juga meningkatkan partisipasi masyarakat untuk aktif dan ikut dalam pemillihan.

\section{REFERENSI}

Ali, Novel. 1999. Peradaban Komunikasi Politik, Bandung: PT. Remaja Rosdakarya

Budiardjo, Mirriam. Dasar-dasar Ilmu Politik, Jakarta: PT. Pustaka Gramedia Utama Koirudin. 2004. Partai Politik dan Agenda Transisi Demokrasi. Yogyakarta: Pustaka Pelajar

Nawawi, Hadawi. 1955. Metode Penelitian Bidang Sosial, Yogyakarta: Gajah Mada University Press

Ramlan Surbakti. 2004. Memahami Ilmu Politikdalam Koirudin. Partai Politik dan Agenda Transisi Demokrasi, Yogyakarta: Pustaka Pelajar.

Singarimbun dan Sofyan Efendy. 1999. Metode Penelitian Sosial Survei, Jakarta : Rajawali Pers 